\title{
UK FOREIGN DIRECT INVESTMENT IN THE OECD, CULTURE AND GEOGRAPHY
}

\author{
Helga Kristjánsdóttir', Fjóla Björk Karlsdóttir²
}

\begin{abstract}
How does distance affect foreign direct investment? Subject of this research is to determine important factors for the United Kingdom, when undertaking foreign direct investment (FDI). The UK is therefore estimated as the home country of investment, investing in the form of FDI in multiple host countries. More specifically, this research measures determinants of FDI outward stock from the UK to other OECD countries. This research examines how distance affects foreign direct investment and provides twofold contribution. First: Hofstede culture distance effects on foreign direct investment is measured. Second: Geographical kilometer distance effects on foreign direct investment is measured. Methodology used in this research is based on the gravity model, presenting a model setup designed for international trade. Moreover, the research applies foreign direct investment OECD data, together with data on gross domestic product and population. The equation specification combines the economic variables with measures for geographical distances, and the Hofstede Culture measure. First regression equation estimates FDI as a function of GDP, population and Culture Distance. Second regression equation estimates FDI as a function of GDP, population and Geographical Distance. This regression setup provides a clear opportunity to estimate the difference between impact of cultural and geographical distance, represented in the estimation coefficients of the regressions. The British Empire has evolved and through time developed the British culture. Purpose of this current research is to examine how cultural distance and geographical distance impact foreign direct investment, with foreign direct investment often being an indicator of the long-term commitment of foreign investors. Furthermore, with the purpose of finding how foreign direct investment is impacted by several different cultural factors, we analyze various dimensions of the Hofstede culture. These are the power distance (PDI), individualism (IDV), the masculinity/femininity (MAS), and the uncertainty avoidance (UAI). Conclusion is that, all taken together, the research finds foreign direct investment from the UK going to other OECD countries to be more highly affected by geographical distance than cultural distance. Which is interesting considering Brexit. Potentially, this is because the UK is not so culturally different from its main trading partners in the OECD, which is an interesting subject for future research.
\end{abstract}

Key words: foreign direct investment, geographical distance, Hofstede national culture, international trade, gravity model, OECD, Brexit.

JEL Classifications: F14, F23, M14, M16, M2

\section{Introduction}

Throughout history, gains from international trade (Markusen, 2004) have stimulated long distance travelling. Moreover, culture is important in trading, since countries still carry on the echoes of different civilizations (Hofstede, 2001). The research question here is, how do these factors impact foreign direct investment (FDI) across borders? This current research seeks to answer that question. Kirkman, Lowe and

Corresponding author:

${ }^{1}$ Faculty of Business Administration, University of Akureyri, Iceland. E-mail: helga@unak.is

ORCID: https://orcid.org/0000-0002-8857-8063

${ }^{2}$ Faculty of Business Administration, University of Akureyri, Iceland.

E-mail: fjolabjork@unak.is

ORCID: https://orcid.org/0000-0002-3263-8418
Gibson (2006) provide a thorough literature review, including introduction of findings showing that FDI decreases with more differences in national culture ( $\mathrm{Li}$ and Guisinger, 1992; Loree and Guisinger, 1995). Moreover, Slagen and Beugelsdijk (2010) findings support indications on cultural distance and geographic distance effects on FDI.

The gravity equation applied in this current research, was developed by Tinbergen (1962) and

\footnotetext{
${ }^{*}$ Helpful comments received during an IMF conference in Iceland, and at the University of Iceland, are highly appreciated.
} 
Pöyhönen (1963) explaining exports as function the GDP of countries, taking into account how distant they are from one another (Larue and Mutunga, 1993). Throughout history, countries have gained an advantage by wisely choosing between if to enter into conventional trade with export and import, or to undertake foreign direct investment (Markusen, 2004). If we fast-forward through history, it appears it has played out as a comparative advantage to have similar culture (Hofstede 1980, 1991, 1994, 2001, Hofstede and Bond 1998) when overcoming distance barriers (Distance Calculator, 2018). The research question seeks to answer whether the difference in countries national Hofstede culture dimensions (Hofstede 1980, 1991, 1994, 2001; Hofstede and Bond 1998) has similar effects as geographical distance (Distance Calculator, 2018) has on international trade and FDI (World Bank, 2016). We hope to illustrate some of the challenges facing countries in the past and the present. The less distance between countries, the more trade (Oguledo and Macphee, 1994). In addition, gross domestic product (GDP) and population can be applied to account for economies of scale along the lines of economic geography (Krugman, 1991; Bergstrand, 1985).

Foreign direct investment (FDI) is what we want to analyze in this current research. Foreign direct investment is investigated and connected with culture and distance, as well as economic GDP, market size, and population. The objective is to establish a relationship between some economic factors, of a country where trade has exploded in volume over the years.

The second section presents literature and model setup. In section three, the data section introduces the data applied in the research, providing variable definition and summary statistics for the sample. Estimation results are then introduced, and finally summary and conclusions.

\section{Literature and Model Setup}

In this current research, we estimate the UK as the home country, investing the form of FDI in multiple host countries, by measuring FDI outward stock from the UK to other OECD countries.

The British Empire evolved through time and developed the British culture. In this current research, we wish to examine how foreign direct investment (FDI) and culture (Hofstede, 1980, 1991, 1994, 2001; Hofstede and Bond. 1998) impacts exports.

We analyse the effects of the Hofstede culture dimensions, these are power distance (PDI), individualism (IDV), masculinity/femininity (MAS), and uncertainty avoidance (UAI).

We start by introducing Equation (1):

$$
P X_{i j}=\beta_{0}\left(Y_{i}\right)^{\beta_{1}}\left(Y_{j}\right)^{\beta_{2}}\left(D_{i j}\right)^{\beta_{3}}\left(A_{i j}\right)^{\beta_{4}} u_{i j}
$$

Equation (1) is based on Bergstrand (1985) model with variable $P X_{i j}$ presenting exports flowing from country i to country j over time t. $Y_{i}$ presents GDP of country $i$ at time $t$, and $Y_{j}$ the GDP of country $j$ at time $t$. $D_{i j}$ is the geographic distance between the country $i$ and country j, with increased distance generally expected to reduce trade. $A_{i j}$ presents factors affecting or restricting trade between country $i$ and $j$. Finally, $u_{i j}$ is a log-normally distributed error term, with $E\left(\ln u_{i j}\right)=0$.

$$
\operatorname{EXP}_{i j, t}=e^{\gamma_{0}}\left(Y_{i, t}\right)^{\gamma_{1}}\left(Y_{j, t}\right)^{\gamma_{2}}\left(D_{i j}\right)^{\gamma_{3}}\left(A_{i j}\right)^{\gamma_{4}} e^{\zeta_{i j, t}}
$$

Equation (2) offers the insertion of population for variable $\mathrm{A}$ into the model.

$$
\operatorname{EXP}_{i j, t}=e^{\varsigma_{0}}\left(G D P_{i, t}\right)^{\varsigma_{1}}\left(P O P_{i, t}\right)^{\varsigma_{2}}\left(D I S_{i j}\right)^{\varsigma_{3}} e^{\varkappa_{i j, t}}
$$

Equation (3) shows the GDP, gross domestic product, and the population POP specification of the model, together with DIS for distance. We next replace exports with FDI, since FDI is one form of international economic activity (Markusen, 2004).

$$
\begin{aligned}
& \ln \ln \left(F D I_{i, t}\right)=\omega_{0}+\ln \omega_{1} \ln \left(G D P_{i, t}\right)+\ln \omega_{2} \ln \left(P O P_{i, t}\right)+ \\
& +\ln \omega_{3} \ln \left(D I S_{\text {_C Culture }}\right)+\xi_{i, t}
\end{aligned}
$$

We further extend the specification in Equation (6), then FDI as a function of culture, GDP and population together with the Hofstede culture dimensions. We therefore go along the lines of some previous use of the Hofstede culture index, explaining international trade (Kristjánsdóttir, 2019a; Kristjánsdóttir, Guðlaugsson, Guðmundsdóttir and Aðalsteinsson, 2017, 2020).

$$
\begin{aligned}
& \ln \ln \left(F D I_{i, t}\right)=v_{0}+\ln v_{1} \ln \left(G D P_{i, t}\right)+\ln v_{2} \ln \left(P O P_{i, t}\right)+ \\
& +\ln v_{3} \ln (\text { DIS_Geographical })+\varsigma_{i, t}
\end{aligned}
$$

Equation (7) provides the FDI as being a function of distance, GDP and population.

Along the lines of the theory presented by Bergstrand (1985) and Keynes (1936), we expect exports to increase with the size of the economy presented with GDP as Y increases.

\section{Data}

This research is based on the UK FDI outward stock data from the OECD. The dataset covers FDI from the UK to other OECD countries, based on the OECD database (OECD, 2016) providing division of UK data to other OECD countries, reporting decomposition of FDI, to individual trading partner countries of the US. The division of FDI from the UK to individual OECD countries is reported on a yearly basis.

The countries included are the following OECD countries, receiving FDI form the UK: Australia, Austria, Belgium, Canada, Chile, the Czech Republic, Denmark, Estonia, Finland, France, Germany, Greece, Hungary, Iceland, Ireland, Israel, Italy, Japan, Korea (the Republic of Korea), Luxembourg, Mexico, the Netherlands, New Zealand, Norway, Poland, Portugal, Slovakia 
(the Slovak Republic), Slovenia, Spain, Sweden, Switzerland, Turkey, the United Kingdom, the United States.

The total number of the OECD countries in the data sample is 34 countries (OECD, 2016). Data covers the years from 1989 to 2012, with the UK FDI being the limiting variable, since it only runs to 2012.

Data on geographical distance is reported in kilometers and obtained from the Distance Calculator (2018).

We choose to eliminate some OECD countries from the sample, since not all five of the Hofstede (2001) culture dimensions are reported for the. The countries eliminated in this current research, since they only report four dimensions, are the following: Chile, Greece, Slovenia and Turkey.

Taken together the five Hofstede (2001) cultural measures interpret that high Power Distance, indicating less equal society. High Individualism indicates that individualism is appreciated. High Masculinity involves that masculinity tends to be appreciated in the society. High uncertainty tolerance implies that societies tend to avoid uncertainty. And finally, high long-term orientation, indicates that there is more patience for waiting in the society. The five Hofstede dimensions do not vary over time.

Variables applied in this current research are defined in Table 1.

The UK Hofstede culture difference, referred to as the UK_Hofstede variable is in the following way:
HOFuk=HOFSTEDEi-hof uk as the outcome when the Hofstede measure for the UK is from each country Hofstede value. Furthermore, the UK_DIS variable is the distance from the UK London capital to the capital city of each country in the sample, except for the USA where New York is instead of the capital city Washington.

Some previous research (Carr, Markusen, Maskus, 2001) has applied skilled labor differences, when estimating international activities. In this current research we apply distance differences, and culture differences when estimating international activities.

\section{Estimation results and discussion}

Table 3 provides estimates on how distance affects the foreign direct investment (FDI) from the UK, to individual OECD countries.

Table 4 estimates measure the effects of Culture are less negative on FDI flowing out of the UK to individual OECD countries, than on EXP from the UK, and more importantly the culture effects are found to have insignificant impact on FDI.

When the results in Table 4 are compared to the results in Table 3, they indicate that the geographical distance has more negative effects than the cultural distance, on the FDI of the UK. Actual geographical distance between countries therefore appears to matter more than cultural distance between them.

Several approaches have been applied to capture determinants of international trade and foreign

Table 1

\section{Variable Definition}

\begin{tabular}{|c|l|}
\hline UK_FDI $I_{i, t}$ & $\begin{array}{l}\text { Foreign Direct Investment FDI, outward from the United Kingdom UK. Reported in United States dollars, US Dollars } \\
\text { (USD). Millions. Obtained from the OECD (2016), on the web-page stats.oecd.org }\end{array}$ \\
\hline UK_GDP $P_{i, t}$ & $\begin{array}{l}\text { Gross Domestic Product GDP of the United Kingdom UK. Reported in US Dollars, current prices. Millions. Obtained } \\
\text { from the OECD (2016) , on the web-page stats.oecd.org }\end{array}$ \\
\hline UK_POP $P_{i, t}$ & Population. All ages. All persons. Annual. Obtained from the OECD (2016), on the web-page stats.oecd.org \\
\hline OTH_GDP $P_{j, t}$ & $\begin{array}{l}\text { Gross Domestic Product GDP of various OECD countries running over j. Reported in US Dollars, current prices. Millions. } \\
\text { Obtained from the OECD (2016) , on the web-page stats.oecd.org }\end{array}$ \\
\hline OTH_POP,$t$, & Population. All ages. All persons. Annual. Obtained from the OECD (2016), on the web-page stats.oecd.org \\
\hline UK_DIS $S_{i, t}$ & $\begin{array}{l}\text { UK distance is the distance from the UK to other countries. Measured as distance in km from the United Kingdom capital } \\
\text { city, London, to other capital cities of countries, except for that in the case of the US New York is applied rather than } \\
\text { Washington DC (Distance Calculator, 2016). }\end{array}$ \\
\hline UK_Hofstede $e_{i, t}$ & $\begin{array}{l}\text { UK Hofstede is the difference between the UK Hofstede measure, and Hofstede measure of other countries. With } \\
\text { Hofstede measure accounted as the accumulated dimensions for each country. }\end{array}$ \\
\hline
\end{tabular}

Table 2

Summary Statistics for the Basic Sample

\begin{tabular}{|c|c|c|c|c|c|}
\hline Variable & Obs & Mean & Std. Dev. & Min & $\operatorname{Max}$ \\
\hline $\ln \left(U K \_F D I_{i, t}\right)$ & 724 & 5.944604 & 2.119853 & .4259211 & 12.05647 \\
\hline $\ln \left(U K \_G D P_{i, t}\right)$ & 1176 & 14.28597 & .3124355 & 13.77242 & 14.68813 \\
\hline $\ln \left(O T H \_G D P_{i, t}\right)$ & 804 & 12.59501 & 1.539574 & 8.574854 & 16.59776 \\
\hline $\ln \left(U K \_P O P_{i, t}\right)$ & 1176 & 17.89607 & .0274194 & 17.85989 & 17.9564 \\
\hline $\ln \left(\mathrm{OTH} \bar{T}_{-} P O P_{i, t}\right)$ & 814 & 16.37921 & 1.524325 & 12.44014 & 19.56526 \\
\hline $\ln \left(\right.$ UK_Distance $\left.{ }_{i, t}\right)$ & 1152 & 7.777442 & 1.059243 & 5.771441 & 9.841612 \\
\hline $\ln \left(U K\right.$ Hofstede $\left.e_{i, t}\right)$ & 696 & 4.457049 & .8364267 & .7442554 & 5.237164 \\
\hline
\end{tabular}


Vol. 6, No. 5, 2020

Table 3

Geographical distance effects on foreign direct investment, based on Equation (4)

\begin{tabular}{|c|c|c|c|c|c|c|}
\hline Linear regression & & & & & Number of obs & $=539$ \\
\hline & & & & & $\mathrm{F}(5,533)$ & $=109.34$ \\
\hline & & & & & Prob $>F$ & $=0.0000$ \\
\hline & & & & & R-squared & $=0.5359$ \\
\hline & & & & & Root MSE & $=1.4343$ \\
\hline & & Robust & & & & \\
\hline $\operatorname{lnUKfdi}$ & Coef. & Std. Err. & $\mathrm{t}$ & $\mathrm{P}>\mathrm{t}$ & [95\% Conf. & Interval] \\
\hline $\operatorname{lnUKgdp}$ & 1.249777 & .4802344 & 2.60 & 0.010 & .3063925 & 2.193161 \\
\hline lnOTHgdp & 2.552213 & .1647092 & 15.50 & 0.000 & 2.228654 & 2.875772 \\
\hline $\operatorname{lnUKpop}$ & -20.29229 & 5.26387 & -3.86 & 0.000 & -30.63277 & -9.951815 \\
\hline lnOTHрор & -1.83521 & .1672735 & -10.97 & 0.000 & -2.163806 & -1.506614 \\
\hline $\operatorname{lnDISuk}$ & -.2087674 & .0592539 & -3.52 & 0.000 & -.3251672 & -.0923676 \\
\hline cons & 350.9077 & 88.48003 & 3.97 & 0.000 & 177.0954 & 524.7201 \\
\hline \multicolumn{7}{|c|}{$\begin{array}{l}\text { Robust t-statistics are reported in par } \\
\text { *** Significant at the } 1 \text { percent level. } \\
\text { ** Significant at the } 5 \text { percent level. } \\
\text { * Significant at the } 10 \text { percent level. }\end{array}$} \\
\hline
\end{tabular}

Table 4

Cultural distance effects on foreign direct investment, based on Equation (5)

\begin{tabular}{|c|c|c|c|c|c|c|}
\hline \multirow{8}{*}{ Linear regression } & & & & & Number of obs & $=428$ \\
\hline & & & & & $F(5,422)$ & $=82.97$ \\
\hline & & & & & Prob $>$ F & $=0.0000$ \\
\hline & & & & & R-squared & $=0.5154$ \\
\hline & & & & & Root MSE & $=1.4151$ \\
\hline & & & & & & \\
\hline & & & & & & \\
\hline & & Robust & & & & \\
\hline $\operatorname{lnUKfdi}$ & Coef. & 364.4958Std. Err. & $\mathrm{t}$ & $\mathrm{P}>\mathrm{t}$ & [95\% Conf. & Interval] \\
\hline $\operatorname{lnUKgdp}$ & $1113228^{* *}$ & 5314235 & 209 & 0037 & 0686612 & 2157705 \\
\hline lnOTHgdp & $2.910743^{* * *}$ & .2458645 & 11.84 & 0.000 & 2.427472 & 3.394015 \\
\hline lnUKpop & $-20.81707^{* * *}$ & 5.631686 & -3.70 & 0.000 & -31.88672 & -9.747416 \\
\hline lnOTHрор & $-2.31361^{* * *}$ & .2784291 & -8.31 & 0.000 & -2.86089 & -1.766329 \\
\hline lnHOFuk & -.1064563 & .0755596 & -1.41 & 0.160 & -.2549763 & .0420638 \\
\hline cons & 364.4958 & 95.19117 & 3.83 & 0.000 & 177.3879 & 551.6037 \\
\hline \multicolumn{7}{|c|}{$\begin{array}{l}\text { Robust t-statistics are reported in parentheses. } \\
\text { *** Significant at the } 1 \text { percent level. } \\
\text { ** Significant at the } 5 \text { percent level. }\end{array}$} \\
\hline
\end{tabular}

direct investment (Davies and Kristjánsdóttir, 2010; Kristjánsdóttir, 2010, 2013, 2016a, 2017, 2019b, 2020; Kristjánsdóttir and Óskarsdóttir, 2020).

Possible adaptations could be to include fixed effects XTFEVD method, accounting for fixed effects, along the lines of Davies, Ionascu and Kristjánsdóttir (2008) who covered inward and outward FDI stock and flows, as well as affiliate sales to capture operational activities of multinational corporations (Beugelsdijk, Hennart, Slangen and Smeets, 2010). The XTFEVD method is applied on FDI in a research by Davies, Ionascu and Kristjánsdóttir (2008), when estimating the impact of time-invariant variables on FDI with fixed. The XTFEVD procedure allows for incorporation for fixed effects in data samples, correcting for the conflation of samples with one home country and multiple host countries of FDI discussed in Van Hoorn (2016) and Brouthers, Marshall and Keig (2016).

\section{Conclusions}

We seek to analyze how foreign direct investment, FDI, flowing out of the United Kingdom to other OECD countries is impacted by geographical distance and culture distance.

The results obtained are novel in the sense that outgoing FDI from the UK is estimated to be less 
impacted by Hofstede culture distance than by geographical distance. In fact, the culture distance effects are estimated to have insignificant effects on the outflow of FDI from the UK.

This indicates that the geographical distance has more significant effects on FDI, that is the further away countries are from the UK, the less FDI they receive.

Within the gravity model setting we also analyze other variables, accounting for the economic size and market size of the UK and the hosting countries of investment.

Our findings indicate that, when considering other variables than geographical or culture distance, the outflowing FDI from the UK is mostly drawn by the economic size of the country receiving the investment, the host country of investment flowing out of the UK, with the economic size being measured with the GDP of the hosting country.

\section{References:}

Bergstrand, J. H. (1985). The Gravity Equation in International Trade: Some microeconomic Foundations and Empirical Evidence, The Review of Economics and Statistics, vol. 67, pp. 474-481.

Beugelsdijk, S., Hennart, J. F., Slangen, A., and Smeets, R.(2010). Why and how FDI stocks are a biased measure of MNE affiliate activity. Journal of International Business Studies, vol. 41, issue 9, pp. 1444-1459.

Brainard, S. L. (1997). An Empirical Assessment of the Proximity-Concentration Trade-off between Multinational Sales and Trade. American Economic Review, vol. 87, no. 4, pp. 520-544.

Brouthers, L. E., Marshall, V. B., and Keig, D. L. (2016). Solving the single-country sample problem in cultural distance studies. Journal of International Business Studies, vol. 47, issue 4, pp. 471-479.

Bond, M. H., and Chi, V. M. Y. (1997). Values and moral behavior in mainland China. Psychological, vol. 40, no. 4, pp. 17-40.

Carr, D. L., Markusen, J. R. and Maskus, K. E. (2001). Estimating the knowledge-capital model of the multinational enterprise. American Economic Review, vol. 91, no. 3, pp. 693-708.

Chung, Y. (2007). The Relationship between Export Marketing Negotiation and National Cultures in Hofstede and Hall's Perspectives, Journal of International Area Studies, vol. 11, no. 1, pp. 253-290.

Davies R. B., Ionascu, D., \& Kristiánsdóttir, H. (2008). Estimating the Impact of Time-Invariant Variables on FDI with Fixed Effects. Review of World Economics, 144(3): 381-407.

Davies R. B., \& Kristjánsdóttir, H. (2010). Fixed Costs, Foreign Direct Investment, and Gravity with Zeros. Review of International Economics, 18(1): 47-62.

Distance Calculator (2018). How Far is it. Available at: http://www.indo.com/distance Obtained March 9

Frank, P. (2012). Expansion Strategies for International Trade and Investment National Culture and Foreign Market Entry: A theory testing Approach. MSc Thesis. School of Management and Governance University of Twente. The Netherlands.

Franke, R. H., Hofstede, G., and Bond, M. H. (1991). Cultural roots of economics performance: A research note, Strategic Management Journal, vol. 12, pp. 165-173.

Harrison, L. E., and Huntington, S. P. (2000). Culture Matters, Basic Books, New York.

Hofstede, G. (1980). Culture's Consequences. New York: Sage.

Hofstede, G. (1991). Cultures and Organizations, Software of the Mind, Maidenhead: McGraw-Hill.

Hofstede, G. (1994). Values Survey Module 1994 Manual, University of Limburg, Maastricht, Holland: Institute for Research on Intercultural Cooperation.

Hofstede, G. (2001). Culture's Consequences: Comparing Values, Behaviors, Institutions, and Organizations across Nations. New York: Sage.

Hofstede, G., and Bond, M.H. (1988). The Confucius Connection: From Cultural Roots to Economic Growth. Organizational Dynamics, vol. 6, no. 4, pp. 4-21.

Hofstede, G. and Hofstede, G. J. (1994). Cultures and Organizations, Software of the Mind: Intercultural Cooperation and Its Importance for Survival. McGraw-Hill.

Hofstede, G., Hofstede, G. J. and Minkov, M. (2010). Cultures and Organizations, software of the mind. Intercultural Cooperation and its importance for survival. New York: McGraw-Hill.

Hofstede, G., Noorderhaven, N. G., Thurik, A. R., Uhlaner, L. M. Wennekers, A. R. M. and Wildeman, R. E. In: Brown, T.E., Ulijn, J. (2004). Innovation, Entrepreneurship and Culture: The interaction between technology, progress and economic growth. Edward Elgar Publishing Limited, MA. USA.

IMD (2012). IMD Infrastructure. Obtained from the IMD. September 23.

Johnson, J. P. and Lenartowicz, T. (1998). Culture, freedom and economic growth: Do cultural values explain economic growth? Journal of World Business, vol. 33, pp. 332-356.

Kandogan, Y. (2016). Economic development, cultural differences and FDI. Applied Economics, vol. 48, no. 17, pp. $1545-1559$.

Keynes, J. M. (1936). The general theory of employment, interest, and money. Macmillan, London. 
Kirkman, B. L., Lowe, K. B., Gibson, C. B. (2006). A quarter century of Culture's Consequences: a review of empirical research incorporating Hofstede's cultural values framework. Journal of International Business, vol. 37, issue 3, pp. 285-320.

Kristjánsdóttir, H. (2010). Foreign Direct Investment: The Knowledge-Capital Model and a Small Country Case. Scottish Journal of Political Economy, 7(5): 591-614.

Kristjánsdóttir, H. (2013). Foreign Direct Investment in a Small Open Economy. Applied Economics Letters. Taylor \& Francis, 20(15): 1423-1425.

Kristjánsdóttir, H. (2016a). Foreign Direct Investment in the Hospitality Industry in Iceland and Norway in comparison to the Nordics and a range of other OECD countries. Scandinavian Journal of Hospitality and Tourism, 16(4): 395-403.

Kristjánsdóttir, H. (2017). Country Competitiveness: An Empirical Study. Baltic Region, 9(2): 31-44. DOI: $10.5922 / 2079-8555-2017-2-3$

Kristjánsdóttir, H. (2019a). Tourism in a Remote Nordic Region: Vat, Internet, Oil, English, Distance, Hofstede, and Christianity. Cogent Social Sciences, 5: 1709346.

Kristjánsdóttir, H. (2019b). Does investment replace aid as countries become more developed? Baltic Journal of Economic Studies, 5(2): 256-261. DOI: 10.30525/2256-0742/2019-5-2-256-261

Kristjánsdóttir, H. (2020). Tax on tourism in Europe: Does higher value-added tax (VAT) impact tourism demand in Europe? Current Issues in Tourism. DOI: 10.1080/13683500.2020.1734550

Kristjánsdóttir, H., Guðlaugsson, P. Ö., Guðmundsdóttir, S., and Aðalsteinsson, G. D. (2017). Hofstede National Culture and International Trade. Applied Economics, 49(57): 5792-5801. DOI: 10.1080/00036846.2017.1343446 Kristjánsdóttir, H., Guðlaugsson, P. Ö., Guðmundsdóttir, S., and Aðalsteinsson, G. D. (2020). Cultural and geographical distance: effects on UK exports. Applied Economics Letters, 27(4):275-279. DOI: $10.1080 / 13504851.2019 .1613495$

Kristjánsdóttir, H., and Óskarsdóttir, S. (2020). EU-Country and Non-EU-Country at the Time of Crisis: Foreign Direct Investment. Baltic Journal of Economic Studies, 6(3), 19-23.

Kristjánsdóttir, H., \& Óskarsdóttir, S. (2021). European FDI in Ireland and Iceland: Before and after the Financial Crisis. Journal of Risk and Financial Management, 14(1), 23. doi:10.3390/jrfm14010023

Krugman, P. (1991). Increasing Returns and Economic Geography. The Journal of Political Economy, vol. 99, no. 3, pp. 483-499.

Larue, B., \& Mutunga, J. (1993). The gravity equation, market size, and black market exchange rates. International Economic Journal, 7: 61-75.

Li, J. T. and Guisinger, S. (1992). The Globalization of Service Multinationals in the Triad Regions - Japan, WesternEurope and North-America. Journal of International Business Studies, vol. 23, issue 4, pp. 675-696.

Loree, D. W. and Guisinger, S. E. (1995). Policy and Non-Policy Determinants of US Equity Foreign DirectInvestment. Journal of International Business Studies, vol. 26, issue 2, pp. 281-299.

Lucke, N. and Eichler, S. (2016). Foreign direct investment: the role of institutional and cultural determinants, Applied Economics, vol. 48, no. 11, pp. 935-956.

Markusen, J. R. (2004). Multinational Firms and the Theory of International Trade, MIT Press, Cambridge, Mass.

Markusen, J. R. (2013). Putting per-capita income back into trade theory, Journal of International Economics, vol. 90 , no. 2, pp. 255-265.

Markusen, J.R. and Venables, A.J. (1998). Multinational firms and the new trade theory, Journal of International Economics, vol. 46, no. 2, pp. 183-203.

Markusen, J.R. and A.J. Venables (2000). The Theory of Endowment, Intra-industry and Multi-national Trade, Journal of International Economics, vol. 52, no. 2, pp. 209-34.

Ng, S. I., Lee, J. A., and Soutar G. N. (2007). Are Hofstede's and Schwartz's value frameworks congruent? International Marketing Review, vol. 24, no. 2, pp. 164-180.

OECD (2016). OECD data. Obtained from: https://stats.oecd.org Downloaded June 25

Oguledo, V. I., \& Macphee, C. R. (1994). Gravity models - a reformulation and an application to discriminatory trade arrangements. Applied Economics, 26:107-120.

Polese, M., \& Shearmur, R. (2004). Is distance really dead? Comparing industrial location patterns over time in Canada. International Regional Science Review, vol. 27, issue 4, pp. 431-457.

Pöyhönen, P. (1963). A tentative model for the volume of trade between countries. Weltwirtschaftliches Archiv, 90: $93-100$.

Shi, X., and Wang, J. (2011). Interpreting Hofstede Model and Globe Model: Which way to go for cross-cultural research? Journal of Business and Management, vol. 6, no. 5, pp. 93-99.

Sivakumar, K., and Nakita, C. (2001). The stampede toward Hofstede's framework: avoiding the sample design pit in cross-cultural research", Journal of International Business Studies, vol. 32, no. 2, pp. 555-574.

Slangen, Arjen H. L., and Beugelsdijk, S. (2010). The impact of institutional hazards on foreign multinational activity: A contingency perspective. Journal of International Business Studies, vol. 41, issue 6, pp. 980-995. 
Straughan, R. D., Albers-Miller N. D. (2001). An international investigation of cultural and demographic effects on domestic retail loyalty, International Marketing Review, vol. 18, no. 5, pp. 521-541.

Stremersch, S., and Tellis, G. J. (2004). Understanding and managing international growth of new products, International Journal of Research and Marketing, vol. 21, no. 4, pp. 421-438.

Tinbergen, J. (1962). Shaping the World Economy: Suggestions for an International Economic Policy. The Twentieth Century Fund, New York.

Van den Bulte, C. and Stremersch, S. (2004). Social contagion and income heterogeneity in new product diffusion: A meta-analytic test", Marketing Science, vol. 23, no. 4, pp. 530-544.

Van Hoorn, A. and Maseland, R. (2016). How institutions matter for international business: Institutional distance effects vs institutional profile effects. Journal of International Business Studies, vol. 47, issue 3, pp. 374-381.

Weber, M. (1947). The Theory of Social and Economic Organization, The Free Press, New York.

World Bank (2016). Data on GDP (current US\$), obtained from the webpage: http://data.worldbank.org/ indicator/NY.GDP.MKTP.CD June 2 th

Yeniyurt, S., and Townsend, J. D. (2003). Does culture explain acceptance of new products in a country? An empirical investigation, International Marketing Review, vol. 20, no. 4, pp. 377-396.

Zaheer, S., and Zaheer, A. (1997). Country effects on information seeking in global economic networks. Journal of international Business studies, vol. 28, pp. 77-100. 